\title{
RPS14 wt Allele
}

National Cancer Institute

\section{Source}

National Cancer Institute. RPS14 wt Allele. NCI Thesaurus. Code C104727.

Human RPS14 wild-type allele is located within 5q31-q33 and is approximately $7 \mathrm{~kb}$ in length. This allele, which encodes 40 S ribosomal protein S14, is involved in translation as a structural protein of the $40 \mathrm{~S}$ ribosome subunit. Loss of this gene may be the cause of $5 q$ deletion syndrome. 